\title{
Fire History in a Chaparral Ecosystem: Implications for Conservation of a Native Ungulate
}

\author{
Vernon C. Bleich, ${ }^{1}$ Heather E. Johnson, ${ }^{2}$ Stephen A. Holl, ${ }^{3}$ Lora Konde, ${ }^{4}$ \\ Steven G. Torres, and Paul R. Krausman ${ }^{6}$ \\ Authors are ${ }^{1}$ Affiliate Faculty, Department of Biological Sciences, Idaho State University, Pocatello, ID 83209, USA; ${ }^{2}$ Research Assistant, College of \\ Forestry and Conservation, University of Montana, Missoula, MT 59812, USA; ${ }^{3}$ Wildlife Biologist, Holl Consulting, Folsom, CA 95630, USA; ${ }^{4}$ Research \\ Program Specialist, California Department of Fish and Game, Bishop, CA 93514, USA; ${ }^{5}$ Senior Environmental Scientist, Wildife Investigations \\ Laboratory, California Department of Fish and Game, Rancho Cordova, CA 95670, USA; and ${ }^{6}$ Boone and Crockett Professor of Wildlife Conservation, \\ College of Forestry and Conservation, University of Montana, Missoula, MT 59812, USA.
}

\begin{abstract}
Mature chaparral vegetation in the San Gabriel Mountains, California, resulting from long fire-return intervals (50-70 yr), has resulted in reduced visibility and availability and quality of forage, all of which are important attributes of mountain sheep (Ovis canadensis) habitat. Concomitantly, vegetation changes have decreased availability and quality of forage. We developed a resource-selection model to determine the effect of fire history on habitat use by mountain sheep, examined the hypotheses that habitat selection was associated with fire occurrence, and determined whether fire occurrence influenced the amount of potential habitat available to mountain sheep. The best model indicated that mountain sheep selected vegetation that had burned within $15 \mathrm{yr}$ and avoided areas that had not burned within that time frame. We then used our model to quantify potential changes in mountain sheep habitat that have occurred over time based on fire conditions. We identified $390 \mathrm{~km}^{2}$ of mountain sheep habitat that existed in 2002 (when only 63 mountain sheep were tallied), $486 \mathrm{~km}^{2}$ in 1980 (when the mountain sheep population was at its highest), and $422 \mathrm{~km}^{2}$ in 2004 (just after a series of large wildfires). We also estimated that $615 \mathrm{~km}^{2}$ of suitable habitat would be available in a hypothetical situation in which the entire study area burned. Our results suggest that restoration of mountain sheep to their historical distribution in chaparral ecosystems will depend upon more frequent fires in areas formerly occupied by those specialized herbivores.
\end{abstract}

\section{Resumen}

La vegetación madura del chaparral en las Montañas San Gabriel, en California, resultado de largos intervalos de regreso del fuego (50-70 años), ha ocasionado reducida visibilidad, así como una baja disponibilidad y calidad de forraje los cuales son atributos importantes del hábitat de las ovejas de montaña (Ovis Canadensis). Asimismo, con los cambios en la vegetación, ha resultado en la disminución de la cantidad y calidad de forraje. Nosotros desarrollamos un modelo de selección de recursos para determinar el efecto histórico del fuego en el uso del hábitat por la oveja de montaña, y examinamos la hipótesis de que la selección del hábitat estaba asociada con la ocurrencia del fuego, la cual afecta al hábitat potencial disponible por las ovejas de montaña. El mejor modelo indicó que las ovejas de montaña seleccionaron vegetación se había quemado en los pasados 15 años, y evitaron áreas que no se habían quemado en ese que mismo periodo de tiempo. Usamos nuestro modelo para cuantificar los cambios potenciales en el hábitat de las ovejas de montaña que han ocurrido con el tiempo basándose en las condiciones del fuego. Identificamos $390 \mathrm{~km}^{2}$ del hábitat de las ovejas de montaña que existía en 2002 (cuando solamente hubo un incremento de 63 ovejas de montaña), $486 \mathrm{~km}^{2}$ en 1980 (cuando se tenía la población mas alta de ovejas de montaña), y $422 \mathrm{~km}^{2}$ (justo después de una serie de grandes incendios). Estimamos también que $615 \mathrm{~km}^{2}$ de hábitat sería apropiado, en una situación hipotética donde toda el área de estudio haya estado sujeta al fuego. Nuestros resultados sugieren que la re-introducción de la oveja de montaña a su distribución histórica en ecosistemas de chaparral dependerá de la ocurrencia de fuegos más frecuente en las áreas que originalmente estuvieron ocupadas por esos herbívoros especializados.

Key Words: California, chaparral, fire, habitat, mountain sheep, Ovis canadensis, restoration

\section{INTRODUCTION}

Research was supported by the California Dept of Fish and Game (CDFG) Resource Assessment Program and the CDFG Sierra Nevada Bighorn Sheep Recovery Program. This is professional paper 053 from the Eastern Sierra Center for Applied Population Ecology.

At the time of this research, Bleich was Senior Environmental Scientist, Sierra Nevada Bighorn Sheep Recovery Program, California Dept of Fish and Game, Bishop, CA 93514, USA; and Krausman was Professor, School of Natural Resources, University of Arizona, Tucson, AZ 85721, USA

Correspondence: Vernon C. Bleich, Eastern Sierra Center for Applied Population Ecology, 11537 36X St SW, Suite 102, Dickinson, ND 58601, USA. Email: vbleich@ndsupernet.com

Manuscript received 10 February 2007; manuscript accepted 3 September 2008.
In the San Gabriel Mountains (SGM), California, the population of mountain sheep (Ovis canadensis) appears to have declined from $740( \pm 49$ SE) sheep in 1980 (when $>500$ animals were tallied) to $<100$ in 2002 (when only 63 were tallied; California Department of Fish and Game, unpublished data, 2002). Mountain sheep inhabiting the SGM are recognized by the US Department of Agriculture Forest Service (Region 5) as a sensitive species and, in 2002, they met criteria for federal endangered status as a distinct population segment 
(Holl 2002). Changes in habitat quality as a result of succession of chaparral vegetation caused by fire suppression (Stephenson and Calcarone 1999) and predation by mountain lions (Puma concolor) have been implicated in this decline (Holl et al. 2004).

Among mountain sheep, those in the SGM are unusual in that they occupy chaparral vegetation for a significant part of their annual cycle (Holl and Bleich 1983). During summer and autumn, those specialized ungulates use conifer and alpine habitats $(>3000 \mathrm{~m})$ that are open and have few visual obstructions. After heavy snows in early winter, males and females descend and occupy areas dominated by chaparral vegetation (900 to $1900 \mathrm{~m}$ ). These winter and spring ranges (henceforth, referred to as W-S ranges) are used November through May (Holl and Bleich 1983); some sheep ascend to higher elevations after snow melts and vegetation begins its annual growth (Holl and Bleich 1983).

Acquisition of nutrients is crucial to reproductive success of female ungulates (Short 1981), which gain body condition until shortly after conception, and then lose condition near the end of lactation (Johns et al. 1984). Nutritional demands are highest during lactation and can limit reproduction if not met (Cook et al. 2004). Because young are born while females occupy W-S ranges, the quality of forage on those ranges is an important factor in the dynamics of the mountain sheep population.

Chaparral is adapted to periodic fire (Barbour and Major 1977). Quality of forage improves for several years following a fire (Taber and Dasmann 1958) and as postfire succession occurs, canopy cover and height of vegetation increase, and the ability of mountain sheep to detect and evade predators decreases (Bleich and Holl 1982; Bleich et al. 1997; Bleich 1999). Additionally, there are concomitant impacts to the foraging efficiency of mountain sheep (Risenhoover and Bailey 1980, 1985). Further, long fire-return intervals $(50-70 \mathrm{yr}$; Stephenson and Calcarone 1999; Minnich 2001) have exacerbated the natural fragmentation (Bleich et al. 1990) of mountain sheep habitat and may have contributed to an increase in predation by mountain lions (Holl et al. 2004). There is, however, little information on responses of mountain sheep to fire in chaparral ecosystems, including the San Rafael and San Bernardino mountains of southern California.

The lack of fire in a variety of other vegetation types and resultant impacts to mountain sheep populations have been described by other investigators. For example, in the Rocky Mountains, Wakelyn (1987) expressed concern about habitat suitability for mountain sheep where fire suppression has been a primary management strategy. Similarly, fire suppression in Madrean Evergreen Woodland ecosystems has negatively affected populations of mountain sheep in southern Arizona (Krausman et al. 1996). As a result of an absence of fire, several investigators have reported substantial differences in vegetation density and visibility when compared with recently burned areas (Wakelyn 1987; Etchberger et al. 1989; Smith et al. 1999; Krausman et al. 2001). Concomitantly, populations of mountain sheep inhabiting areas of extended periods of fire suppression have declined substantially (Krausman et al. 1979).

Approximately $22 \%$ of W-S range occupied by mountain sheep in the SGM burned in 1968, 1970, and 1975, increasing nutrient availability and open habitat conditions favored by

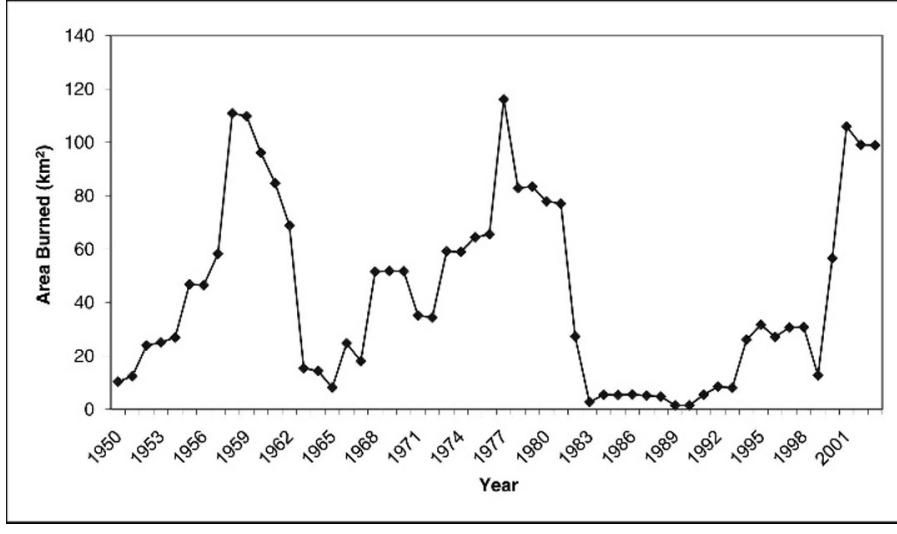

Figure 1. Five-year running average of area burned (in square kilometers) in the San Gabriel Mountains, Los Angeles and San Bernardino counties, California, from 1950 to 2003.

mountain sheep before the population peak of 1980 (Holl et al. 2004). During the ensuing decades, few large fires occurred in mountain sheep habitat, vegetation continued to mature, and habitat openness declined (which likely increased vulnerability of mountain sheep to predation by mountain lions). The fewest mountain sheep were tallied in 2002, and the population apparently reached its lowest level in $>35 \mathrm{yr}$ (Holl et al. 2004). A series of fires burned approximately $27 \%$ of the eastern SGM during autumn 2003, with potential benefits to mountain sheep habitat (Fig. 1).

We used data from annual population surveys and detailed habitat information to identify factors correlated with mountain sheep habitat use in SGM. Specifically, we examined the hypotheses that the distribution of mountain sheep is affected by the fire history of chaparral and by time because the most recent fire would be inversely related to habitat use by mountain sheep. To do this, we used a resource-selection function model (RSF; Manly et al. 2002) to identify habitat selection by mountain sheep relative to topographic features, vegetation types, human disturbance, and fire history. We then simulated habitat use by mountain sheep across the SGM given the habitat conditions of 1980 (when the mountain sheep population was at its peak), in the year 2002 (when the fewest sheep were tallied), and in 2004 (just after major wildfires had occurred). The 2004 model also allowed us to identify areas that would be of benefit to mountain sheep if burned.

\section{METHODS}

\section{Study Area}

The SGM (lat $34^{\circ} 14^{\prime} \mathrm{N}$, long $117^{\circ} 43^{\prime} \mathrm{W}$ ), in Los Angeles and San Bernardino counties, California, are one of a series of transverse ranges that extend approximately $110 \mathrm{~km}$ from coastal southern California eastward to the Mojave Desert. Currently, mountain sheep occupy eight $\mathrm{W}-\mathrm{S}$ ranges, dominated by chaparral, in the east end of the SGM (Holl and Bleich 1983; Holl et al. 2004). Available evidence suggests those ungulates once had a wider distribution within the transverse ranges (Buechner 1960) where mountain sheep occupied chaparral ecosystems in the San Bernardino and the San Rafael mountains. 
Elevations in the SGM range from $260 \mathrm{~m}$ at the base of that range in the Los Angeles Basin to $3350 \mathrm{~m}$ at Mt San Antonio. Cismontane foothills lie between $260 \mathrm{~m}$ and $530 \mathrm{~m}$. Desert slopes on the north side of the range lie at an elevation of about $1000 \mathrm{~m}$, and transmontane foothills are between $1000 \mathrm{~m}$ and $1200 \mathrm{~m}$ in elevation. The SGM are a steep and highly faulted block of metamorphic rock and are dissected by numerous deep canyons that support perennial flows of water (Holl and Bleich 1983). The climate is Mediterranean, with hot, dry summers and moist, mild winters (Bailey 1966).

Vegetation is diverse (Hanes 1976; Barbour and Major 1977); Holl and Bleich (1983) provided detailed descriptions of vegetation used by mountain sheep. Chaparral (i.e., the shrub formation of Holl and Bleich [1983] that is used by mountain sheep during late winter and early spring) is dominant between elevations of $300 \mathrm{~m}$ and $1800 \mathrm{~m}$ on cismontane slopes, which face south toward the Pacific Ocean. Characteristic species include chaparral whitethorn (Ceanothus leucodermis E. Greene), hoaryleaf ceanothus (Ceanothus crassifolius Torrey), chamise (Adenostoma fasciculatum Hook \& Arn.), mountain mahogany (Cercocarpus betuloides Torrey \& A. Gray), Nuttall's scrub oak (Quercus dumosa Nutt.), white sage (Salvia apiana Jepson), and California buckwheat (Eriogonum fasciculatum Benth.; Holl and Bleich 1983). Extensive areas of coastal sage scrub occur below the chaparral zone, and open Alpine associations predominate at high elevations; mixed hardwood and conifer forests occur on steep, north-facing slopes at intermediate elevations and receive limited use by mountain sheep (Holl and Bleich 1983). Plant nomenclature follows Hickman (1993).

Mammal species diversity in the SGM is high and, with the exception of grizzly bears (Ursus arctos; Storer and Tevis 1955), the SGM support a full complement of native carnivores capable of preying upon large ungulates, including bobcat (Lynx rufus), mountain lion, and coyote (Canis latrans; Vaughan 1954). Black bears (Ursus americanus), which are potential predators of mule deer (Odocoileus hemionus) and mountain sheep, were translocated to the SGM in 1933 (Burghduff 1935).

Mule deer and mountain sheep both are dependent on chaparral to meet life history needs (Bleich and Holl 1982). Mule deer that inhabit chaparral typically are not migratory and generally have small home ranges (Linsdale and Tomich 1953; Taber and Dasmann 1958), but exceptions exist (e.g., Nicholson et al. 1997). Mountain sheep inhabiting the SGM may remain on W-S ranges for extended periods or migrate to higher elevation summer ranges to obtain nutritional benefits associated with changes in plant phenology (Holl and Bleich 1983). Shrubs comprise approximately $60 \%$ of mountain sheep diets annually (Perry et al. 1987). Mule deer and mountain sheep are sympatric on chaparral-dominated slopes of the SGM when nutritional requirements of both species are high.

\section{Habitat Modeling}

Standardized aerial and ground surveys were conducted concurrently on W-S ranges occupied by mountain sheep in the SGM each March from 1979 to 1989 , but only aerial surveys occurred during 1990-2002 (Holl et al. 2004). Sightability may be affected by vegetative cover and animal activity (Samuel et al. 1987; Bodie et al. 1995; Bleich et al. 2001). Virtually all groups recorded by aerial observers were moving, suggesting that animals behaved similarly, regardless of seral stage of vegetation. Shifts in habitat use can occur in response to helicopter disturbance (Bleich et al. 1994), but concordance between simultaneous ground and aerial observations (Bleich 1998) indicated such movements were not problematic. Thus, we concluded that visibility of mountain sheep to aerial observers was similar throughout our investigation, that our observation rate was not unduly biased by vegetation succession, and that locations at which mountain sheep were seen accurately reflected habitat used by those herbivores.

We classified mountain sheep by sex and age (Geist 1968; Bleich 1982) and plotted the location of each group on US Geological Survey (USGS) 7.5' topographic maps. We eliminated duplicate observations (Bleich 1998), assigned social groups to categories, and converted locations to digital format. For our analyses, a group consisted of $\geq 1$ mountain sheep. During surveys, individuals $\leq 50 \mathrm{~m}$ from each other were considered to be in the same group (Siegfried 1979). We recognized three social groups of mountain sheep (adapted from Hirth 1977). Female groups contained $\geq 1$ mature ( $\geq 2 \mathrm{yr}$ ) female but could include male or female yearlings or lambs. Male groups contained $\geq 1$ mature ( $\geq 2 \mathrm{yr}$ ) male but could also contain yearling males. Mixed groups contained $\geq 1$ adult male and $\geq 1$ female and any additional individuals.

We used multiple logistic regression to 1 ) identify variables most associated with springtime habitat use and 2) estimate parameters to model resource selection by mountain sheep. To meet these objectives we compared resources at "used" locations (i.e., locations at which mountain sheep were observed) to those at randomly selected "available" locations (Boyce et al. 2002; Manly et al. 2002). We used 1171 locations where mountain sheep were observed from 1979 to 2002. We randomly selected $80 \%$ of those locations to be used for habitat model development (i.e., training data) and withheld $20 \%$ of the locations to validate the model (i.e., testing data).

We defined available habitat as all areas within the $100 \%$ minimum convex polygon (MCP), or convex hull, of all used March locations with an additional 1-km buffer surrounding that MCP (Bleich et al. 1997; Nielsen et al. 2002). Within that available habitat we used a geographic information system (GIS) and stratified random sampling to select locations for comparison. We overlaid available habitat with a $500 \times$ $500 \mathrm{~m}$ grid and generated a random location within each cell of the grid. We produced 2161 available locations to include in model development; model precision is often improved by including more available locations than used locations (Fielding and Haworth 1995; Gross et al. 2002) because available locations usually include more variation than used locations.

We considered 10 variables in the habitat model: elevation, slope, aspect, hill shade, terrain ruggedness, distance to escape terrain, vegetation type, distance to roads, distance to trails, and fire history. All of these variables have been identified as factors affecting habitat selection by mountain sheep (Smith et al. 1991; Bleich et al. 1997; Andrew et al. 1999; McKinney et al. 2003; Oehler et al. 2005; DeCesare and Pletscher 2006), but the importance of fire history has not been quantified. Changes in resource availability or habitat characteristics are important 


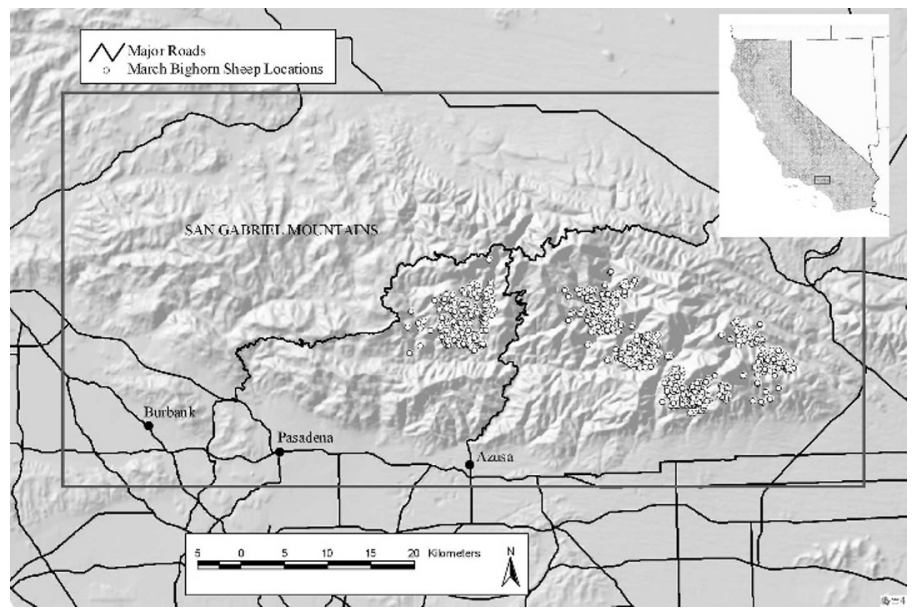

Figure 2. The San Gabriel Mountain range with March helicopter survey locations of mountain sheep, Los Angeles and San Bernardino counties, California, 1979-2002.

considerations when assessing habitat selection (Arthur et al. 1996; Mysterud and Ims 1998), but, with the exception of fire history, habitat characteristics in our model likely remained constant during the period population data were collected. Indeed, the majority of the SGM occupied by mountain sheep is legislated wilderness and changes in distances to roads or trails were not an issue because none were constructed during our investigation. With the exception of perturbations associated with wildfires, climax vegetation was not subject to change during our investigation. Fire resulted in dramatic changes within specific vegetation classes (i.e., the seral stage of chaparral vegetation), but it did not alter categories of major vegetation types. With the exception of perturbations in chaparral habitat associated with fire, availability of resources to mountain sheep was similar from year to year because survey areas and protocols were standardized and restricted to specific winter ranges occupied by mountain sheep (Holl and Bleich 1983; Holl et al. 2004).

We developed a digital raster layer for each predictor variable across the area of interest (Fig. 2). Raster layers were based on a $30 \times 30 \mathrm{~m}$ grid, and we assigned to every pixel a value for each habitat variable. We obtained elevations from 30-m USGS Digital Elevation Models (DEM) and used the DEM to derive values for slope, aspect, and hill shade. We coded aspect as one of eight categorical variables $(\mathrm{N}, \mathrm{NE}, \mathrm{E}$, $\mathrm{SE}, \mathrm{S}, \mathrm{SW}, \mathrm{W}$, and $\mathrm{NW}$ ) using $\mathrm{S}$ as the reference value in model development. We used hill shade (the hypothetical illumination of a surface according to a specified azimuth and altitude for the sun) as an index to sun exposure. We set the azimuth at $225^{\circ}$ and the angle of the sun at $45^{\circ}$, so higher values would represent xeric southwest slopes, and lower values would represent mesic northeast slopes (Nielsen et al. 2002). We estimated terrain ruggedness for each pixel by calculating the product of the standard deviation of slope and the mean angular deviation of aspect for each of its nine surrounding pixels (Zar 1984; Nicholson et al. 1997). Because mountain sheep characteristically are associated with escape terrain (i.e., steep, rocky slopes; Bleich et al. 1997; Andrew et al. 1999; Oehler et al. 2005), we also calculated the distance to escape terrain for each pixel in the study area. We defined escape terrain as any pixel having $>60 \%$ slope (Holl 1982; Smith et al. 1991; Singer et al. 2000; McKinney et al. 2003). We determined distance-to-roads and distance-to-trails from USGS 1:100 000-scale digital line graphs.

We used a US Forest Service vegetation map derived from satellite imagery to categorize each pixel as chaparral, hardwood, conifer, mixed hardwood/conifer, or barren. The chaparral category was used as the reference class in model development. We obtained fire history information from the California Department of Forestry and Fire Protection Fire Perimeters Coverage; this layer identified the locations and years of all fires that occurred in the SGM from 1878 to 2004. We categorized each pixel based on the number of years since last burned ( $<5 \mathrm{yr}, 6-10 \mathrm{yr}, 11-15 \mathrm{yr}, 16-20 \mathrm{yr}, 21-25 \mathrm{yr}$, $26-30 \mathrm{yr}$, and $>30 \mathrm{yr}$ ) and used $<5 \mathrm{yr}$ as the reference class. Because the effects of fire on chaparral are short-lived (Stephenson and Calcarone 1999), all pixels that had not burned in $>30 \mathrm{yr}$ were coded identically.

We recorded locations of mountain sheep for a period of $23 \mathrm{yr}$; thus, the time-since-burned value for a pixel was dependent upon the fire history of that location in any particular year. To accurately determine the importance of fire to resource selection by mountain sheep, we calculated timesince-burned for each pixel in which a mountain sheep location fell based on the year of the sighting and the fire history of that pixel for that year. Available locations were randomly assigned a year between 1979 and 2002 (i.e., the years of mountain sheep observations). Using GIS, a time-since-burned value was attributed to each available location based on the fire history of the year to which it was randomly assigned. As a result, we were able to allow the time-since-burned value of a pixel to vary depending on the year of the survey (real or simulated) and, thus, to evaluate the importance of fire to habitat selection across time. All other habitat predictor variables were assumed to remain constant over the course of the study.

We identified topographic, vegetative, anthropomorphic, and fire characteristics important in describing habitat selection by mountain sheep. We used parsimonious model-building techniques to determine variables that should be included (Hosmer and Lemeshow 1989). We first conducted univariate analyses for all predictor variables, using a cutoff of $P<0.25$ for the Wald $z$ statistic for inclusion in the final model. We examined habitat variables for multicollinearity to ensure that no two variables were highly correlated. Slope and distance-toescape-terrain were strongly correlated $(r=0.67)$; thus, we removed the distance-to-escape-terrain variable from further analysis. For all other combinations of variables, $r$ was $<0.30$. To develop the best possible predictive model, we started with all the aforementioned explanatory variables and used a backwards stepwise approach to remove variables that did not significantly $(P>0.20)$ improve model fit. With our final set of variables, we also added second-order polynomial terms where appropriate (Hosmer and Lemeshow 1989). Once a model that included all mountain sheep locations was developed, we separated "used" locations by type of mountain sheep social group (i.e., female, male, or mixed) and recalculated coefficients of explanatory variables to determine whether there were significant differences. We examined the significance, magnitude, and direction of the coefficients and 
compared group models to the overall model (Nielsen et al. 2002).

We used coefficients from the logistic regression model to calculate RSF values (Manly et al. 2002):

$$
w(x)=\exp \left(\beta_{0}+\beta_{1} x_{1}+\ldots+\beta_{p} x_{p}\right)
$$

where $x_{\mathrm{i}}$ are the independent habitat-predictor variables, and $\beta_{\mathrm{i}}$ represents the coefficients of those variables. To validate the population-level RSF model, we used a procedure for use-availability designs with the $20 \%$ testing data that was withheld from model development (Howlin et al. 2004). Then, we calculated RSF values to simulate mountain sheep habitat availability based on past, present, and future fire events. First, we calculated RSF values based on the fire history of vegetation in 2002, the last year of our location data, when only 63 individuals were recorded. Thus, to calculate RSF values, all pixels were assigned a years-since-burned category based on pixel-specific fire history information for 2002. From the simulated landscape, we identified the pixels with the highest $10 \%$ of values (Boyce et al. 2002) and considered those pixels to have the greatest potential value as mountain sheep habitat. Next, we calculated RSF values based on fire information from 1980, the year when the mountain sheep population was at its peak, and for 2004, after the major wildfires occurred. We applied the cutoff value specifying the highest $10 \%$ pixels from the 2002 calculations to the 1980 and 2004 RSF maps to determine the relative amount of area that exceeded the cutoff value for each scenario.

We conducted a final calculation to predict the potential effects of future prescribed fire on habitat selection. For this evaluation we manipulated fire history values so that all pixels were coded as burned-within-the-last-5-yr and, while retaining all other habitat characteristics, recalculated RSF values. Again, we used the cutoff value for the highest $10 \%$ RSF pixels identified from the 2002 calculations (our baseline) and determined the amount of area that would exceed the cutoff value and, potentially, be mountain sheep habitat, if burned. This manipulation allowed us to identify areas where additional burns would significantly increase the probability of use by mountain sheep, given the 2004 fire conditions in the SGM.

\section{RESULTS}

Habitat predictor variables included in the final logistic model were elevation, elevation ${ }^{2}$, slope, hillshade, terrain ruggedness, distance to roads, distance to trails, aspect, and fire history $\left(-2 \mathrm{LL} \quad\left[\right.\right.$ deviance] $=-1535.83, \chi^{2}=717.89, \quad P<0.001$, $r^{2}=0.19$; Table 1). On W-S ranges, mountain sheep were observed most frequently in areas that were intermediate in elevation; had steep, xeric slopes; were closer to roads; were further from trails; had eastern aspects; and that had burned within $15 \mathrm{yr}$. Model coefficients indicated that mountain sheep avoided areas that had not burned in $>15 \mathrm{yr}$. There was no evidence of major differences in selection among female, male, or mixed groups of mountain sheep when compared with coefficients from the population-level model (i.e., nonoverlapping $95 \%$ confidence intervals [95\% CI]; Nielsen et al. 2002). Validation procedures (Howlin et al. 2004) classified the habitat model as a good fit $(\beta=0.98,95 \% \mathrm{CI}=0.73,1.23$; $\left.\mathrm{F}_{1,18}=68.56, P<0.001\right)$.

We used the highest $10 \%$ of RSF values and identified $390 \mathrm{~km}^{2}$ of suitable habitat in 2002, after the population had declined substantially (S. A. Holl, unpublished data, 2007), and $85 \%$ of the W-S range had not burned for 18 years (Fig. 3). Based on the cutoff value that identified this top $10 \%$ of the pixels in the 2002 calculation, the 1980 RSF values identified $486 \mathrm{~km}^{2}$ of mountain sheep habitat exceeding the cutoff value, a relative indicator of habitat availability when the population was at its maximum (Fig. 4). Using the same cutoff value the 2004 RSF values identified $422 \mathrm{~km}^{2}$ of mountain sheep habitat after the major wildfires (Fig. 5). From the 2004 RSF map, we simulated burning the entire study area and identified a total of $615 \mathrm{~km}^{2}$ that would exceed the specified cutoff (Fig. 6).

\section{DISCUSSION}

Logistic regression RSF models based on use-availability designs have been criticized for potentially not being truly proportional to the probability of use because the data are "contaminated" by some proportion of randomly selected "available" locations that were likely "used" by bighorn sheep (Keating and Cherry 2004). Despite this shortcoming, logistic regression produces valid parameter estimates for use in RSF models. Indeed, RSF models based on logistic regression are generally robust (Manly et al. 2002; Johnson et al. 2006) and have important application in wildlife studies (Boyce and McDonald 1999) and in conservation planning.

Elevation, slope, terrain ruggedness, hillshade, aspect, and distances to disturbance factors have been identified as variables important in habitat selection by mountain sheep, and our results are consistent with previous reports (Bleich et al. 1997; Andrew et al. 1999; Bleich 1999; Holl et al. 2004; Cain et al. 2005; Oehler et al. 2005). Although we identified highly significant relationships between the distribution of mountain sheep and a number of variables (Table 1), our results indicated that fire history (i.e., time since burned) had an overwhelming influence on distribution of mountain sheep on W-S ranges relative to other explanatory variables. In our final model, fire history is the variable most apt to influence openness and also enhances forage quality and availability.

We identified a strong positive association between mountain sheep and areas burned up to $15 \mathrm{yr}$ postconflagration and a strong negative association between mountain sheep and chaparral $>15 \mathrm{yr}$ postconflagration (Table 1). During spring, when mountain sheep are concentrated on low-elevation ranges, they selected recently burned chaparral and avoided areas of dense chaparral that characterized older burns. Ruggedness of terrain and openness of vegetation (i.e., horizontal visibility) are characteristic of most ecosystems occupied by mountain sheep, a species that is highly dependent on visual cues to evade predation (Bleich 1999).

Chaparral is a fire-adapted vegetation type (Barbour and Major 1977), where infrequent but high-intensity fires increase 
Table 1. Multiple logistic-regression coefficients for the final mountain sheep habitat selection model developed for the San Gabriel Mountains, Los Angeles and San Bernardino counties, California, 1979-2002.

\begin{tabular}{|c|c|c|c|c|}
\hline Habitat variable & Coefficient & SE & $z$ & $P>Z$ \\
\hline Elevation & 0.0099 & 0.0009 & 11.50 & $<0.001$ \\
\hline Elevation $^{2}$ & $<0.0001$ & $<0.0001$ & -12.34 & $<0.001$ \\
\hline Slope & 0.0609 & 0.0062 & 9.90 & $<0.001$ \\
\hline Hillshade & 0.0046 & 0.0020 & 2.31 & 0.021 \\
\hline Terrain ruggedness & 0.0009 & 0.0002 & 4.00 & $<0.001$ \\
\hline Distance to roads & 0.0004 & $<0.0001$ & 10.01 & $<0.001$ \\
\hline Distance to trails & -0.0001 & $<0.0001$ & -1.52 & 0.128 \\
\hline \multicolumn{5}{|l|}{ Aspect $^{\mathrm{a}}$} \\
\hline North & 0.1409 & 0.3352 & 0.42 & 0.674 \\
\hline Northeast & 0.0213 & 0.3681 & 0.06 & 0.954 \\
\hline East & 0.3076 & 0.3013 & 1.02 & 0.307 \\
\hline Southeast & 0.2197 & 0.1934 & 1.14 & 0.256 \\
\hline Southwest & -0.4757 & 0.1685 & -2.82 & 0.005 \\
\hline West & -0.3636 & 0.1619 & -2.25 & 0.025 \\
\hline Northwest & -0.1416 & 0.2117 & -0.67 & 0.504 \\
\hline Year since burned ${ }^{\mathrm{b}}$ & - & - & - & - \\
\hline $6-10 \mathrm{yr}$ & 0.7557 & 0.2553 & 2.96 & 0.003 \\
\hline $11-15 \mathrm{yr}$ & 0.5277 & 0.2447 & 2.16 & 0.031 \\
\hline $16-20 \mathrm{yr}$ & -0.8968 & 0.3011 & -2.98 & 0.003 \\
\hline $21-25 \mathrm{yr}$ & -0.2005 & 0.2417 & -0.83 & 0.407 \\
\hline $26-30 \mathrm{yr}$ & -0.8153 & 0.2716 & -3.00 & 0.003 \\
\hline$>30 \mathrm{yr}$ & -0.2926 & 0.1993 & -1.47 & 0.142 \\
\hline Constant & -10.2574 & 0.8427 & -12.17 & $<0.001$ \\
\hline
\end{tabular}

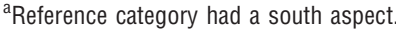

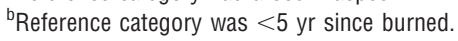

forage quality in the short term (Taber and Dasmann 1958) and, in the SGM, improve habitat suitability for mountain sheep for about $15 \mathrm{yr}$. Similar responses have been observed in other ranges where burning enhanced forage quality (Hobbs and Spowart 1984; Seip and Bunnell 1985; Smith et al. 1999). Indeed, DeCesare and Pletscher (2006) reported that recently burned areas were preferred by mountain sheep and that lowvisibility, densely vegetated areas were avoided in Montana.

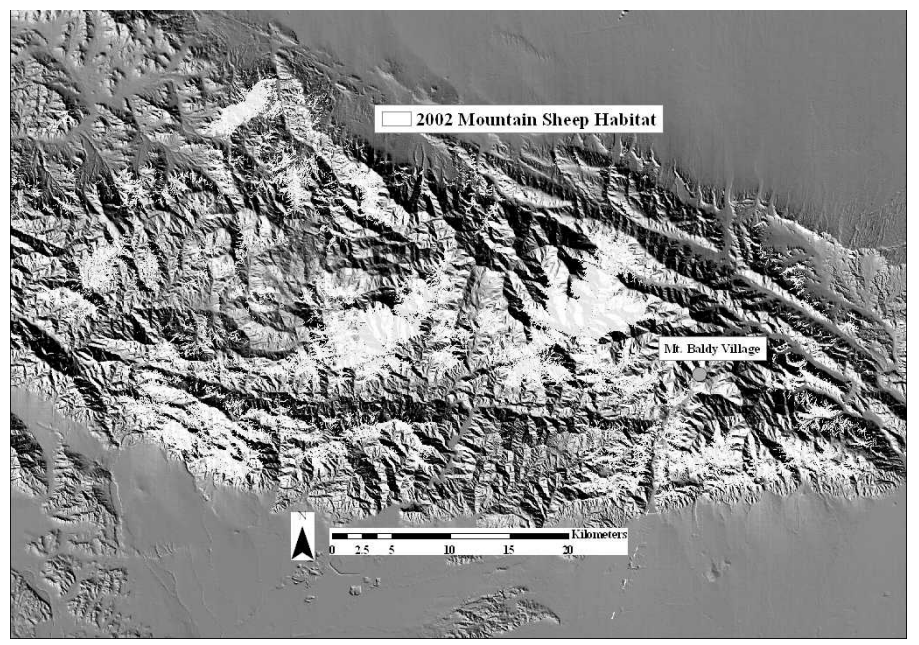

Figure 3. Available mountain sheep habitat identified from the resource-selection probability model of the San Gabriel Mountains, Los Angeles and San Bernardino counties, California, 2002.
Similarly, Smith et al. (1999) reported increased use of burned areas in Utah. DeCesare and Pletscher (2006) and Smith et al. (1999) both suggested that availability and quality of forage, in addition to visual openness, were factors affecting selection of burned areas by mountain sheep. Without recurrent fires, it is likely that persistence of populations reliant on W-S ranges dominated by chaparral vegetation in the SGM will be in jeopardy.

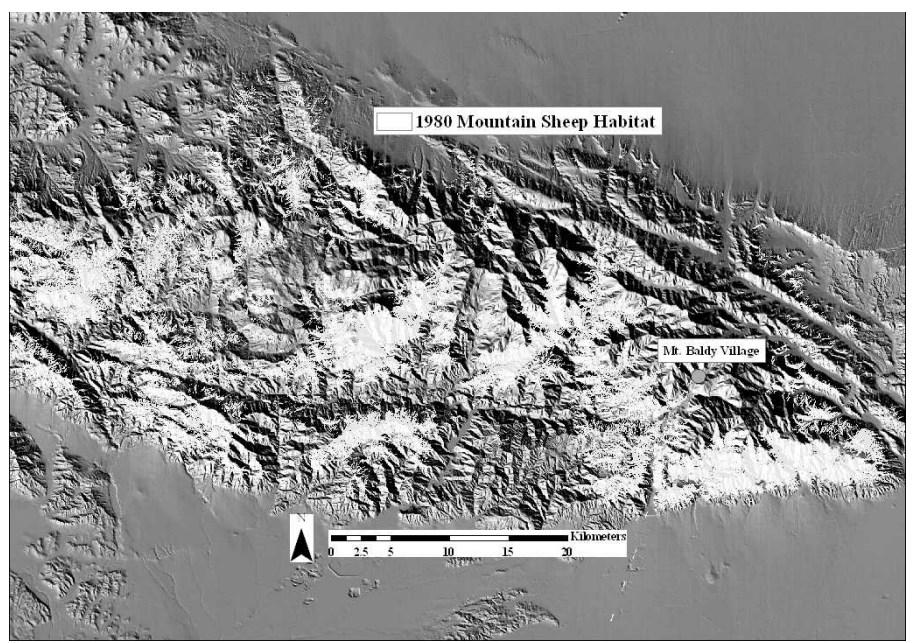

Figure 4. Available mountain sheep habitat identified from the resource-selection probability model of the San Gabriel Mountains, Los Angeles and San Bernardino counties, California, 1980. 


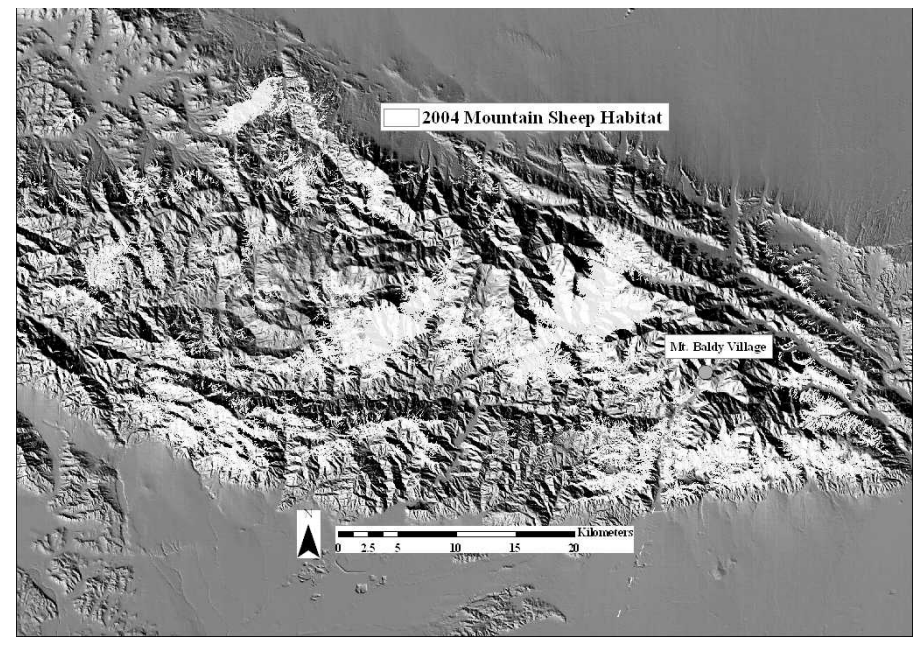

Figure 5. Available mountain sheep habitat identified from the resource-selection probability model of the San Gabriel Mountains, Los Angeles and San Bernardino counties, California, 2004.

Studies of treatment effects have important implications in wildlife science and, particularly, in providing meaningful information to managers (Guthery et al. 2004). Although the literature incorporates references linking the effects of fire and habitat suitability in some ecosystems occupied by mountain sheep, investigators have not previously considered the role of fire history nor have they examined responses of mountain sheep to fire over an extended timeline. Holl et al. (2004) identified a relationship between fire history and number of mountain sheep inhabiting the SGM, but the mechanism driving that relationship has, until now, largely been speculative. Our results are valuable in that they not only indicate that ignitions in chaparral ecosystems are important components affecting habitat selection but also that intervals at which fires occur are of great significance. Further, our results allow us to evaluate selection or avoidance as a function of years-sinceburned, and habitat selection is likely the mechanism by which population size and fire history are linked; until now, that relationship had not been quantified.

Ecosystems that support substantially fewer large mammals than under pristine conditions are depauperate from functional perspectives, i.e., large herbivores play pivotal roles as a prey base for large carnivores (Bowyer et al. 2005), and in nutrient cycling (Kie et al. 2003). As a result, restoration of populations of large ungulates to historical ranges will contribute both to biodiversity and ecosystem function. Mountain sheep are slow to colonize new areas (Geist 1970; Bleich et al. 1996), and that reticence is exacerbated in the diminution or absence of suitable habitat, both of which occur in ecosystems, such as chaparral, that are characterized by long fire-return intervals.

The volume of existing information, the recent availability of detailed habitat and geographic data in digital format, and the fires that occurred between 1968 and 2003 enabled us to assess the importance of a number of attributes to mountain sheep habitat selection in the SGM. This assessment was possible because of serendipitous wildfires but provides direction and guidance to land managers with respect to management of fire in chaparral ecosystems, the effects of those actions on availability and suitability of habitat for mountain sheep and,

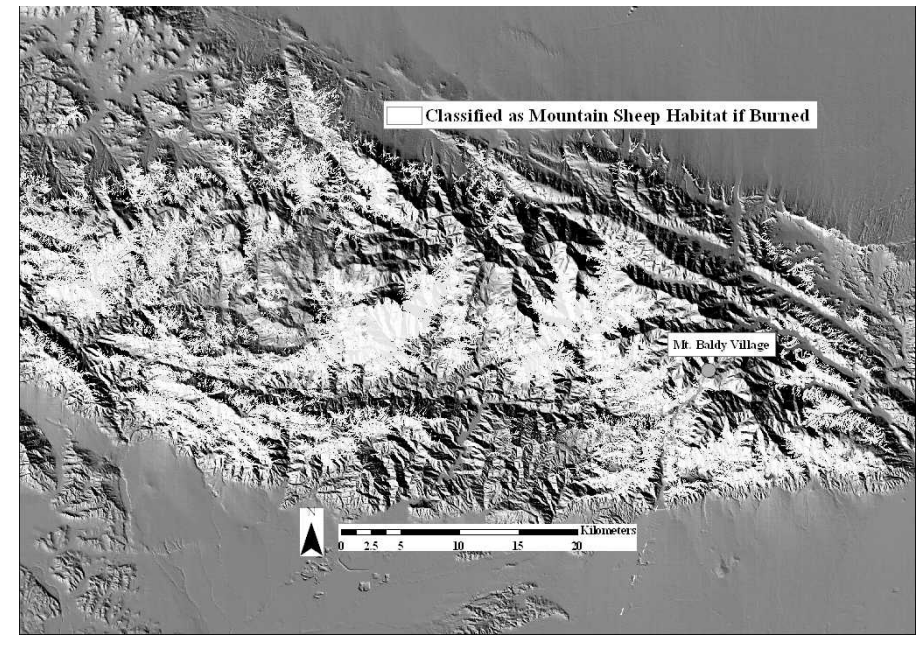

Figure 6. Area identified by resource-selection model that would currently be classified as mountain sheep habitat if burned, San Gabriel Mountains, Los Angeles and San Bernardino counties, California.

as a consequence, the potential to restore populations of those large herbivores. Mountain sheep habitat occurs on steep, rocky terrain, where machinery cannot operate, and fire is the only practical tool to modify habitat suitability (Biswell et al. 1952; Bleich and Holl 1982). The restoration strategy for this mountain sheep population (Holl 2004) identified prescribed burns that should be implemented, and the recently updated land management plans for the Angeles and San Bernardino national forests recognized the need to implement those burns, even in designated wilderness areas (US Department of Agriculture Forest Service 2005).

The value of habitat selection models can be enhanced if lifehistory parameters, such as survival rates (Nielsen et al. 2006), forage availability (Nielsen et al. 2003), and recruitment rates can be assessed and incorporated into more complex models (Nielsen et al. 2006). Density (Van Horne 1983) or occupancy (Hobbs and Hanley 1990) alone can be poor indices to population performance, but our results are, nonetheless, important for the conservation of biodiversity in chaparral ecosystems where mountain sheep once were more widely distributed (Hall and Kelson 1959; Buechner 1960; Trefethen 1975). Our results clearly demonstrate the importance of fire to habitat selection by mountain sheep in chaparral ecosystems and provide a platform on which future investigators may base more complex models, similar to those developed by Nielsen et al. (2006), as data become available.

\section{IMPLICATIONS}

Our results have important implications for restoring and maintaining high-quality habitat for mountain sheep on chaparral-dominated W-S ranges. We delineated those areas in the SGM that, with the exception of fire history, were identified by the RSF as being potentially selected by mountain sheep. Those results can be used to identify additional areas within the transverse ranges where unintended conflagrations or prescribed fire would have a positive effect on habitat suitability for those large herbivores. Application of models to 
areas removed from those in which they were developed should take a cautionary approach (Schooley 1994), but areas so identified provide an objective starting point when evaluating locations to reestablish mountain sheep in areas dominated by climax chaparral vegetation and that previously were occupied by those specialized ungulates.

Selection of chaparral habitat that has burned within $15 \mathrm{yr}$ is significant from the standpoint of conservation of mountain sheep. A 15-yr fire-return interval is inconsistent, however, with the range of natural variation in such systems, and more frequent burning increases the spread of exotic herbaceous plants (Keeley and Fotheringham 2003) and is not recommended herein as a management goal. Nevertheless, use of prescribed fire to simulate a more natural fire regime, and thereby to enhance availability and suitability of habitat, should receive serious consideration by land managers when evaluating reintroduction sites or when mountain sheep populations occupying chaparral ecosystems are substantially below historical levels.

\section{ACKNOWLEDGMENTS}

We thank the numerous biologists and volunteers that participated in the annual surveys that resulted in the data reported on herein. We also thank S. R. DeJesus, B. K. Novak, and in particular, the late J. D. Landells for expertise in mountain flying, and J. P. Marshal for meaningful comments on an earlier draft of this paper. R. A. Weaver contributed in many meaningful ways to the completion of this investigation, and we acknowledge his enthusiastic support. The Society for the Conservation of Bighorn Sheep was instrumental in organizing ground surveys and provided logistical support that was indispensable. F. S. Guthery, E. H. Merrill, and G. A. Sargeant provided helpful suggestions that markedly improved the manuscript.

\section{LITERATURE CITED}

Andrew, N. G., V. C. Bleich, and P. V. August. 1999. Habitat selection by mountain sheep in the Sonoran Desert: implications for conservation in the United States and Mexico. California Wildlife Conservation Bulletin 12:1-30.

Arthur, S. M., B. F. J. Manley, L. L. McDonald, and G. W. Garner. 1996. Assessing habitat selection when availability changes. Ecology 77:215-227.

Balley, H. P. 1966. The climate of southern California. Berkeley, CA, USA: University of California Press. 87 p.

Barbour, M. G., and J. Major. 1977. Terrestrial vegetation of California. New York, NY, USA: John Wiley and Sons. $1014 \mathrm{p}$.

Biswell, H. D., R. D. Taber, D. W. Hedrick, and A. M. Schultz. 1952. Management of chamise brushlands for game in the north coast region of California. California Fish and Game 38:453-484.

BLEICH, V. C. 1982. An illustrated guide to aging the lambs of mountain sheep. Desert Bighorn Council Transactions 26:59-62.

BLEICH, V. C. 1998. Importance of observer experience in classifying mountain sheep. Wildlife Society Bulletin 26:877-880.

BLEICH, V. C. 1999. Mountain sheep and coyotes: patterns of predator evasion in a mountain ungulate. Journal of Mammalogy 80:283-289.

Bleich, V. C., R. T. Bowyer, A. M. Pauli, M. C. Nicholson, and R. W. Anthes. 1994. Responses of mountain sheep Ovis canadensis to helicopter surveys: ramifications for the conservation of large mammals. Biological Conservation 45:1-7.

Bleich, V. C., R. T. Bowyer, and J. D. Wehausen. 1997. Sexual segregation in mountain sheep: resources or predation? Wildlife Monographs 134:1-50.

Bleich, V. C., C. S. Y. Chun, R. W. Anthes, T. E. Evans, and J. K. Fischer. 2001. Visibility bias and development of a sightability model for tule elk. Alces 37:315-327.
Bleich, V. C., AND S. A. Holl. 1982. Management of chaparral habitat for mule deer and mountain sheep in southern California. In: C. Conrad and W. C. Oechel [TECH COORDS.]. Dynamics and management of Mediterranean ecosystems. Berkeley, CA, USA: US Department of Agriculture, Forest Service, Pacific Southwest Forest and Range Experiment Station. General Technical Report PSW-58. p. 247-254.

Bleich, V. C., J. D. Wehausen, and S. A. Holl. 1990. Desert-dwelling mountain sheep: conservation implications of a naturally fragmented distribution. Conservation Biology 4:383-390.

Bleich, V. C., J. D. Wehausen, R. R. Ramey II, and J. L. Rechel. 1996. Metapopulation theory and mountain sheep: implications for conservation. In: D. R. McCullough [ED.]. Metapopulations and wildlife conservation. Covelo, CA, USA: Island Press. p. 353-373.

Bodie, W. L., E. O. Garton, E. R. Taylor, and M. McCoy. 1995. A sightability model for bighorn sheep in canyon habitats. Journal of Wildlife Management 59:832-840.

Bowyer, R. T., D. K. Person, and B. M. Pierce. 2005. Detecting top-down versus bottom-up regulation of ungulates by large carnivores: implications for biodiversity. In: J. C. Ray, K. H. Redford, R. S. Steneck, and J. Berger [EDS.]. Large carnivores and the conservation of biodiversity. Covelo, CA, USA: Island Press. p. 342-361.

Boyce, M. S., AND L. L. McDonald. 1999. Relating populations to habitats using resource selection functions. Trends in Ecology and Evolution 14:268-272.

Boyce, M. S., P. R. Vernier, S. E. Nielsen, and K. A. Schmiegelow. 2002. Evaluating resource selection functions. Ecological Modelling 157:281-300.

BueCHNeR, H. K. 1960. The bighorn sheep in the United States, its past, present, and future. Wildlife Monographs 4:1-168.

Burghduff, A. E. 1935. Black bears released in southern California. California Fish and Game 21:83-84.

Cain, J. W., III, H. E. Johnson, and P. R. Krausman. 2005. Wildfire and desert bighorn sheep habitat, Santa Catalina Mountains, Arizona. Southwestern Naturalist 50:506-513.

Cook, J. G., B. K. Johnson, R. C. Cook, R. A. Riggs, T. Delcurto, L. D. Bryant, and L. L. IRWIN. 2004. Effects of summer-autumn nutrition and parturition date on reproduction and survival of elk. Wildlife Monographs 155:1-61.

DeCesare, N. J., and D. H. Pletscher. 2006. Movements, connectivity, and resource selection of Rocky Mountain bighorn sheep. Journal of Mammalogy 87:531-538

Etchberger, R. C., P. R. Krausman, and R. MazaiKa. 1989. Mountain sheep habitat characteristics in the Pusch Ridge Wilderness, Arizona. Journal of Wildlife Management 53:902-907.

Fielding, A. H., AND P. F. Haworth. 1995. Testing the generality of bird-habitat models. Conservation Biology 9:1466-1481.

GEIST, V. 1968. On the interrelation of external appearance, social behavior and social structure of mountain sheep. Zeitschrift fur Tierpsychologie 25:199-215.

GEIST, V. 1970. Mountain sheep. Chicago, IL, USA: University of Chicago Press. $383 p$.

Gross, J. E., M. C. Kneeland, D. F. Reed, and R. M. Reich. 2002. GIS-based habitat models for mountain goats. Journal of Mammalogy 83:218-228.

Guthery, F. S., Jefrerey J. Lusk, and M. J. Peterson. 2004. In my opinion: hypotheses in wildlife science. Wildlife Society Bulletin 32:1325-1332.

Hall, E. R., and K. R. Kelson. 1959. Mammals of North America. New York, NY, USA: Ronald Press Company. 1083 p.

Hanes, T. L. 1976. Vegetation types of the San Gabriel Mountains. In: J. Latting [ED.]. Proceedings of the Symposium on Plant Communities of Southern California; 4 May 1974. Berkeley, CA, USA: California Native Plant Society. p. 65-76.

HickMAn, J. C. [ED.]. 1993. The Jepson manual. Los Angeles, CA, USA: University of California Press. 1400 p.

HIRTH, D. H. 1977. Social behavior of white-tailed deer in relation to habitat. Wildlife Monographs 53:1-55

HobBs, N. T., AND T. A. Hanley. 1990. Habitat evaluation: do use/availability data reflect carrying capacity? Journal of Wildlife Management 54:515-522.

HobBS, N. T., and R. A. Spowart. 1984. Effects of prescribed fire on nutrition of mountain sheep and mule deer during winter and spring. Journal of Wildlife Management 48:551-560. 
HolL, S. A. 1982. Evaluation of desert bighorn sheep habitat. Desert Bighorn Council Transactions 26:47-49.

HoLL, S. A. 2002. Conservation strategies for bighorn sheep in the San Gabriel Mountains, California. Folsom, CA, USA: Steve Holl Consulting.

HoLL, S. A. 2004. Implementation strategy to restore the San Gabriel Mountains bighorn sheep population. Folsom, CA, USA: Steve Holl Consulting.

Holl, S. A., AND V. C. BleICH. 1983. San Gabriel mountain sheep: biological and management considerations. San Bernardino, CA, USA: San Bernardino National Forest. $136 \mathrm{p}$.

Holl, S. A., V. C. Bleich, And S. G. TorRes. 2004. Population dynamics of mountain sheep in the San Gabriel Mountains, California, 1967-2002. Wildlife Society Bulletin 32:412-426.

Hosmer, D. W., AND S. Lemeshow. 1989. Applied logistic regression. New York, NY, USA: John Wiley and Sons. $216 p$.

Howlin, S., W. P. ERICKSon, and R. M. Nielson. 2004. A proposed validation technique for assessing predictive abilities of resource selection functions. In: S. Huzurbazar [ED.]. Resource selection methods and applications. Laramie, WY, USA: Omnipress. p. 40-51.

Johns, P. E., M. H. Smith, And R. K. Chesser. 1984. Sex and age effects on seasonal fat levels in a southeastern white-tailed deer herd. Journal of Wildlife Management 48:969-972.

Johnson, C. F., S. E. Nielsen, E. H. Merrill, T. L. McDonald, and M. S. Boyce. 2006. Resource selection functions based on use-availability data: theoretical motivation and evaluation methods. Journal of Wildlife Management 70:347-357.

Keating, K. A., and S. Cherry. 2004. Use and interpretation of logistic regression in habitat-selection studies. Journal of Wildlife Management 68:774-789.

KeEley, J. E., AND C. J. Fotheringham. 2003. Impact of past, present, and future fire regimes on North American Mediterranean shrublands. In: T. T. Veblen, W. L. Baker, G. Montenegro, and T. W. Swetmen [EDs.]. Fire and climatic change in temperate ecosystems of the western Americas. New York, NY, USA: Springer. p. 218-262.

Kie, J. G., R. T. Bowyer, and K. M. Stewart. 2003. Ungulates in western forests: habitat requirements, population dynamics, and ecosystem processes. In: C. J. Zabel and R. G. Anthony [EDS.]. Mammal community dynamics: management and conservation in the coniferous forests of western North America. New York, NY, USA: Cambridge University Press. p. 296-340.

Krausman, P. R., W. C. Dunn, L. K. Harris, W. W. Shaw, and W. M. Boyce. 2001. Can mountain sheep and humans coexist? In: R. Field, R. J. Warren, H. Okarma, and P. R. Sievert [EDS.]. Wildlife, land, and people: priorities for the $21 \mathrm{st}$ century. Proceedings of the Second International Wildlife Management Congress; 28th June-2 July 1999; Godollo, Hungary. Bethesda, MD, USA: Wildlife Society. p. 224-227.

Krausman, P. R., R. G. Long, and L. Tarango. 1996. Desert bighorn sheep and fire, Santa Catalina Mountains, Arizona. In: P. F. Ffolliott, L. Debano, M. B. Baker, Jr., G. J. Gottfried, G. Solis-Garza, C. B. Edminster, D. G. Neary, L. S. Allen, and R. H. Hamre [TECH COORDS.]. Effects of fire on Madrean Province ecosystems. Fort Collins, CO, USA: US Department of Agriculture, Forest Service, General Technical Report RM-289. p. 162-168.

Krausman, P. R., W. W. Shaw, and J. L. StaiR. 1979. Bighorn sheep in the Pusch Ridge Wilderness Area, Arizona. Desert Bighorn Council Transactions 23:40-46.

Linsdale, J., and P. Q. Tomich. 1953. A herd of mule deer. Berkeley, CA, USA: University of California Press. 567 p.

Manly, B. F. J., L. L. McDonald, D. L. Thomas, T. L. McDonald, and W. P. Erickson. 2002. Resource selection by animals: statistical design and analysis for field studies. 2nd ed. Boston, MA, USA: Kluwer Academic Publishers. $216 \mathrm{p}$.

McKinney, T., S. R. BoE, AND J. C. DeVos, JR. 2003. GIS-based evaluation of escape terrain and desert bighorn sheep populations in Arizona. Wildlife Society Bulletin 31:1229-1236.

Minnich, R. A. 2001. An integrated model of two fire regimes. Conservation Biology 15:1549-1553.

Mysterud, A., AND R. A. Ims. 1998. Functional responses in habitat use: availability influences relative use in trade-off situations. Ecology 79:1435-1441.

Nicholson, M. C., R. T. BowyeR, AND J. G. KIE. 1997. Habitat selection and survival of mule deer: tradeoffs associated with migration. Journal of Mammalogy 78:483-504.
Nielsen, S. E., M. S. Boyce, G. B. Stenhouse, and R. H. M. Munro. 2002. Modeling grizzly bear habitats in the Yellowhead ecosystem of Alberta: taking autocorrelation seriously. Ursus 13:45-56.

Nielsen, S. E., M. S. Boyce, G. B. Stenhouse, and R. H. M. Monro. 2003. Development and testing of phenologically driven grizzly bear habitat models. Ecoscience 10:1-10.

Nielsen, S. E., G. B. Stenhouse, and M. S. Boyce. 2006. A habitat-based framework for grizzly bear conservation in Alberta. Biological Conservation 130:217-229.

Oehler, M. W., V. C. Bleich, R. T. Bowyer, and M. C. Nicholson. 2005. Mountain sheep and mining: implications for conservation and management. California Fish and Game 91:149-178.

Perry, W. M., J. W. Dole, and S. A. Holl. 1987. Analysis of diets of mountain sheep in the San Gabriel Mountains, California. California Fish and Game 73:156-162.

Risenhoover, K. L., AND J. A. Balley. 1980. Visibility: an important habitat factor for an indigenous, low-elevation bighorn herd in Colorado. In: B. Hickey [ED.]. Proceedings of the Biennial Symposium of the Northern Wild Sheep and Goat Council; Salmon, ID, USA. Cody, WY, USA: Northern Wild Sheep and Goat Council. p. 18-28.

Risenhoover, K. L., AND J. A. Bailey. 1985. Foraging ecology of mountain sheep: implications for habitat management. Journal of Wildlife Management 49:292-804.

Samuel, M. D., E. O. Garton, M. W. Schlegel, and R. G. Carson. 1987. Visibility bias during aerial surveys of elk in northcentral Idaho. Journal of Wildlife Management 51:622-630.

SCHOoLey, R. L. 1994. Annual variation in habitat selection: patterns concealed by pooled data. Journal of Wildlife Management 58:367-374.

Selp, D. R., and F. L. Bunnell. 1985. Nutrition of Stone's sheep on burned and unburned ranges. Journal of Wildlife Management 49:397-405.

Short, H. L. 1981. Nutrition and metabolism. In: 0. C. Wallmo [ED.]. Mule and black-tailed deer of North America. Lincoln, NE, USA: University of Nebraska Press. p. 99-127.

Siegfried, W. R. 1979. Vigilance and group size in springbok. Madoqua 12:151-154.

Singer, F. J., V. C. Bleich, And M. A. Gudorf. 2000. Restoration of bighorn sheep metapopulations in and near western national parks. Restoration Ecology 8:14-24.

Smith, T. S., J. T. Flinders, AND D. S. Winn. 1991. A habitat evaluation procedure for Rocky Mountain bighorn sheep in the intermountain west. Great Basin Naturalist 51:205-225.

Smith, T. S., P. J. Hardin, And J. T. Flinders. 1999. Response of bighorn sheep to clear-cut logging and prescribed burning. Wildlife Society Bulletin 27:840-845.

Stephenson, J. R., and G. M. Calcarone. 1999. Southern California mountains and foothill assessment; habitat and species conservation issues. Albany, CA, USA: US Department of Agriculture, Forest Service, Pacific Southwest Forest and Range Experiment Station, General Technical Report PSW-172. 402 p.

StoreR, T. I., And L. P. Tevis. 1955. The California grizzly. Berkeley, CA, USA: University of California Press. 335 p.

TABER, R. D., AND R. F. DASMAnn. 1958. The black-tailed deer of the chaparral: its life history and management in the north Coast Range of California. California Department of Fish and Game, Game Bulletin 8:1-163.

Trefethen, J. B. 1975. The wild sheep in modern North America. New York, NY, USA: Winchester Press. 302 p.

uS Department of Agriculture Forest Service. 2005. Land management plan: part 2-San Bernardino National Forest strategy. Washington, DC, USA: Government Printing Office, Report R5-MB-079.

Van Horne, B. 1983. Density as a misleading indicator of habitat quality. Journal of Wildlife Management 47:893-901.

Vaughan, T. A. 1954. Mammals of the San Gabriel Mountains of California. University of Kansas Publications, Museum of Natural History 12:1-153.

WAKelYN, L. A. 1987. Changing habitat conditions on bighorn sheep ranges in Colorado. Journal of Wildlife Management 51:904-912.

Zar, J. H. 1984. Biostatistical analysis. 2nd ed. Englewood Cliffs, NJ, USA: Prentice-Hall. $718 \mathrm{p}$. 